\title{
The Bubble and the Lost Decade
}

\author{
Gary R. Saxonhouse and Robert M. Stern
}

\section{INTRODUCTION}

$\mathfrak{A}$ LITTLE more than a dozen years ago, in 1989, Japan was completing a decade of excellent economic performance. Its 3.9 per cent average annual rate of growth of gross domestic product, while slower than what it had achieved in any earlier decade since 1950, was still significantly better than the performance of the world's other advanced industrialised economies. During this same decade, equity prices rose six-fold and land prices more than four-fold. ${ }^{1}$

Even as equity and land prices increased dramatically, in 1989, many economists were prepared to argue that the new valuations were justified by Japan's economic fundamentals. ${ }^{2}$ Japan's distinctive, but superior system of economic management, both at the government level and within the firm, it was argued, justified more optimistic expectations of further exceptional economic growth even as Japan's unusually high national savings rate kept real interest rates lower than those in other major industrialised economies. Indeed, its distinctive economic system was seen as working so well by comparison with those of other major economies that Japan was hailed by Chalmers Johnson (1989) as the only 'Communist nation that works.'

In March 2002, when the Symposium was convened in Ann Arbor at which earlier versions of the papers were presented, Japan looked very different. Japan's post-1989 GDP growth has averaged no more than 1.2 per cent annually, worse than that of any other major industrialised country. Japan's equity markets, after reaching a peak at the end of 1989, have fallen by 75 per cent. Japanese land prices have fared still worse with prices falling by 80 per cent, so that in 2002, Japanese land prices are below levels prevailing 20 years ago. Thus,

GARY R. SAXONHOUSE and ROBERT M. STERN are from the University of Michigan (Ann Arbor). The papers in this issue were prepared initially for a Symposium held on 22 March, 2002, at the University of Michigan. Support was provided by the Japan Foundation, Centre for Global Partnership. The latter stages of Saxonhouse's work on this project were facilitated by a residency at the Rockefeller Foundations Bellagio Study and Conference Center.

1 See Figure 1 in Takatoshi Ito's Symposium paper below.

${ }^{2}$ Frankel (1991) reviews much of this literature. 
Chalmers Johnson who wrote in 1989 that 'Japan is the only Communist nation that works' more recently (1998) has written that 'Japan truly fits the crony capitalism description that has complacently continued to protect its structurally corrupt and sometimes gangster-ridden firms.' As Nishimura and Kawamoto show in their Symposium paper below, the very economic institutions, such as community banking and permanent employment (and they might have added close government-business relationships) that for four decades were seen as enhancing Japanese growth prospects are now seen as standing in the way of renewed superior economic performance.

With hindsight, it is easy to criticise the failure of so many observers in the late 1980s to foresee the marked change that was about to occur in Japan's economic fortunes. In light of the experience of the United States in the 1990s, however, it is clear that such failures are not unique to Japan. In both Japan in the late 1980s and in the United States in the late 1990s, prices of assets, such as equities and land, rose rapidly even while the prices of goods and services were relatively stable. In such an environment, it admittedly is difficult to determine, until after the fact, whether the asset-price increases represent speculative excess or a secular change in the rate of growth of productivity. But, for our purposes, we will assume that a bubble did occur in Japan. With this in mind the Symposium that follows seeks to explore: (1) whether the bubble could have been prevented; (2) how much of the economic pain that Japan faced during the 1990s was the result of the bubble's collapse; and (3) what can be done today to help resolve Japan's continuing economic problems. ${ }^{3}$

\section{COULD THE BUBBLE HAVE BEEN PREVENTED?}

Takatoshi Ito addresses the first of the issues raised above in his Symposium paper. Mindful that it is difficult to know that a bubble has occurred until after it is over, Ito suggests that the Bank of Japan (BOJ), at the time of the Louvre Accord in February 1987, should not have cut the discount rate from 3 to 2.5 per cent. Failing that, he argues that the BOJ discount rate could still have been raised in August 1988 when the Federal Reserve and the Bundesbank raised interest rates. According to Ito, earlier tightening of monetary policy might have nipped the bubble in the bud, but even in the summer of 1988 tightening credit conditions might still have prevented some of the worst problems that ultimately arose. By May 1989 when the discount rate was finally raised, according to Ito, it was too late.

${ }^{3}$ These and other current issues pertinent to Japan are also explored in depth in the papers in Stern (2003). 
To underline how politically difficult it might have been for the BOJ to raise its discount rate, it should be remembered that, during the very years that Ito says that the BOJ should have reversed policy, many observers abroad were not only praising Japan's economic institutions, they were also praising the quality of Japanese macroeconomic management for simultaneously keeping interest rates low and inflationary expectations damped. For example, David Hale, a highly influential US business economist, wrote in August 1989 that:

During the second half of the decade, it was the Japanese MOF [Ministry of Finance] which used a mixture of direct intervention and moral suasion to protect the US financial system from sharply rising interest rates at a time when foreign private investors lost confidence in the US dollar.

... the MOF and the BOJ pursued a low interest rate policy to boost the US dollar during 198788 and neutralized the potential inflationary consequences on credit growth through administrative guidance (pp. 60-61).

Likewise, in 1988, C. Fred Bergsten, the Director of the Institute for International Economics, praised Japanese policies:

Since 1986, in perhaps its most impressive performance to date, Japan has adjusted to a near doubling in the dollar value of the yen by shifting with remarkable speed from the export-led growth of the early 1980s to a domestic-led expansion that has produced a burst of rapid growth despite the steady decline of its trade balance in real terms.

Japan's new Five-Year Plan (1988-92) projects GNP growth of 3.75 percent annually and growth in domestic demand of 4.25 percent annually.... It ... seems both desirable and feasible for Japan to exceed targets in the plan, perhaps maintaining domestic demand at about 6 percent annually. In fact, domestic demand growth reached an estimated 7.4 percent in 1988 (pp. 63 and 103).

Quite apart from an earlier move to more restrictive macroeconomic policies, Ito suggests that stricter prudential policies, had they been adopted, could have had a significant impact on the magnitude of the bubble. Ito believes that Japanese authorities could have: (1) introduced a regulation (or guidance) on the loan/value ratio on real estate lending, citing the increased risk of realestate-price volatility; and (2) issued a regulation (or guidelines) to limit lending to real-estate-related sectors, citing the risks of concentrating loans too heavily in a single sector.

Many market participants in the late 1980s already recognised that these very steps, that Ito now recommends with hindsight, were required. Interestingly enough, they believed that the Japanese government was taking just such measures. Quoting again from Hale:

The BOJ ordered the banks to reduce the growth rate of total lending and sharply curtailed the supply of funds available for property speculation. As a result, the growth rate of bank lending for real estate fell from $32 \%$ to $8 \%$ and there was a modest decline in Tokyo real estate prices during 1987 and 1988 despite a monetary policy which was highly accommodating in every 
other respect. The MOF also used restrictions on land availability to prevent the slowdown in property lending from producing a price collapse $e^{4}$ (p. 62).

After rising rapidly from 8 to 13 per cent between 1980 and 1986, loans to the real estate sector as a percentage of total loans to Japan's city banks, as Hale suggests, did not increase further. This was insufficient, however, to puncture the nation-wide land bubble. ${ }^{5}$ It was only in 1990 when the BOJ capped total loans and, not just their proportion to total lending, that the bubble began to show signs of bursting.

\section{THE BUBBLE AND JAPAN'S PROBLEMS IN THE 1990s}

Whether the bubble could have been prevented is one issue. To what extent it was responsible for the host of the problems that the Japanese economy faced during the 1990s and continues to face today is another. The Symposium papers are in agreement that the equity and real estate bubble's bursting need not have caused a dozen years of travail for Japan. With a different set of policies, Japan might have recovered in a few years' time.

\section{a. Ineffective Fiscal Policy}

In their Symposium paper, Ihori, Nakazato and Kawade blame the prolonged recession and slow recovery on the macroeconomic measures pursued by the MOF. Neither government spending nor tax cuts did much to stimulate the economy. These findings are particularly interesting because recent influential work by Kuttner and Posen (2001), like Ihori et al., use vector auto regressions (VAR) to do their analysis of Japanese fiscal policy, but unlike Ihori et al., conclude that, when used, fiscal policy was effective. ${ }^{6}$ While Kuttner and Posen blame the Lost Decade on insufficient use of fiscal measures, Ihori et al. find fiscal policy

\footnotetext{
4 While Hale's numbers may surprise some, his bank-lending statistics are from those of the BOJ, while his Tokyo real-estate-price data are taken from the official National Land Agency series. See also Figure 2 below in the Nishimura and Kawamoto Symposium paper. Writing in mid-1989, Hale did not know that whatever success the BOJ had in restraining bank lending in 1987 and 1988 was not matched in 1989 when bank loans for real estate grew at 14.7 per cent and when Tokyo land prices once again started rising. Werner (2002) characterises Japanese government policy in exactly the opposite way from Hale. Werner argues that the BOJ used 'window guidance' to push a reluctant Japanese banking sector to continue to extend new loans to the real estate sector.

5 Nihon ginkō, Nihon tōkei nenkan Heisei-rokunen (Tokyo, 1995). Unlike Tokyo, nationally land prices continued to increase throughout 1987 and 1988.

${ }^{6}$ R. Glenn Hubbard (2002), the Chairman of the Council of Economic Advisers, cites the fiscal policy results of Kuttner and Posen. Ramaswamy and Rendu (2000) come to conclusions similar to those of Ihori et al.
} 
becoming ineffective in the 1990s as concerns about the size of Japan's public debt grew. Some of the differences in findings between Kuttner and Posen and Ihori et al. can be attributable to differences in the data sets being used. Kuttner and Posen used annual data and assumed that macroeconomic relationships that held before and during the bubble also held in the 1990s. ${ }^{7}$ In contrast, Ihori et al. used quarterly data and therefore have enough observations to allow relationships in the 1990s to be different from those prevailing earlier. ${ }^{8}$

\section{b. The Domestic Consequences of International Finance}

While Ihori et al. focus exclusively on macroeconomic policy in attempting to make sense of what happened to Japan in the 1990s, the Symposium papers by Goyal and McKinnon and by Fukao look more directly at interaction between microeconomic and macroeconomic issues. The bursting of the bubble in 1990 and thereafter meant that many of the loans made in the 1980s to the real estate sector by Japanese banks could not be repaid. Japanese banks, the BOJ, and the MOF were slow to publicly acknowledge the scale of this problem. A quick write-off of these non-performing loans would have left most Japanese banks too thinly capitalised (or worse) to continue operations without a new infusion of capital. Given the uncertain environment and the lack of reliable information about the financial condition of Japan's banks, this capital infusion could only come from the Japanese Government. But for much of the decade the use of public money in this way to bail out Japan's banks was politically impossible.

In contrast to the position taken by Ito, both Goyal and McKinnon and Fukao emphasise that, given the small spread in the 1990s between loan rates and deposit rates, such an infusion of capital would have failed. While these two papers reach similar conclusions, their analyses are quite different. Goyal and McKinnon note that for much of the past 25 years interest rates on Japanese loans tended to move

\footnotetext{
${ }^{7}$ Kuttner and Posen include a linear time trend and a trend interacted with a post-1990 dummy in their model.

${ }^{8}$ Tamim Bayoumi, in commenting on the Ihori et al. paper when it was presented in Ann Arbor, argued that quarterly national income accounts in Japan are not very reliable. As evidence, Bayoumi noted: (1) the standard deviation of the consensus forecast among business economists is high; (2) Japanese equity markets rarely respond to the release of quarterly national-incomeaccount data; and (3) the quarterly national-income-accounts data in Japan are subject to unusually large revisions. But, it may be noted, Japan's annual national-income-accounts data, particularly the government fiscal data, are also fraught with many of the same problems as the quarterly accounts and are viewed by many as not giving an accurate picture of government behaviour. See Ando (2002). Using quarterly national-income-accounts data, in the context of the FRB/Global Market Model, Ahearne et al. (2002) come to conclusions about the efficacy of fiscal policy similar to those of Kuttner and Posen. However, it should be pointed out that the VAR methods of the sort used by both Ihori et al. and Kuttner and Posen are a response to criticism that macroeconometric models such as the FRB/Global are not overidentified as their builders commonly assumed. This critique is contained in the seminal paper by Sims (1980).
} 
in tandem with US interest rates even while always maintaining a substantial negative differential. For the period up until 1995, Goyal and McKinnon attribute this pattern to relatively stable expectations of a continuing increase in the value of the yen relative to the dollar. ${ }^{9}$ Since 1995 even as these expectations have evaporated, this differential has persisted, reflecting the premium that the heavily-indebted United States has to pay creditor nations to bear the exchange risk associated with holding dollar-denominated debt.

According to Goyal and McKinnon, as long as interest rates in the United States were relatively high, the negative differential between the US and Japanese interest rates did not pose special and unique problems for the conduct of economic policy in Japan. As interest rates have fallen in the United States, however, Japanese interest rates have increasingly been pushed towards zero and into a liquidity trap. ${ }^{10}$ With interest rates near zero, monetary policy has lost its effectiveness as a means of economic recovery. Since the early 1990s substantial increases in bank reserves have not gone hand-in-hand with substantial increases in bank credit to the private sector. With compressed lending rates and the zero lower bound on deposit rates, and hence with low profit margins on new commercial lending, Goyal and McKinnon emphasise that banks have an incentive to change their portfolio allocation away from commercial lending into low transaction-cost government bonds. In this low profit-margin environment, unlike US banks in the early 1990s, the Japanese banks cannot gradually re-capitalise themselves after writing off their non-performing loans. Nor, in this environment, will an injection of capital from the Japanese Government make Japanese banks any more likely to be more aggressive in extending loans. ${ }^{11}$

\section{c. Deregulation, Corporate Governance, and Government-sponsored Financial Institutions}

Unlike Goyal and McKinnon, Fukao maintains that macroeconomic considerations are insufficient to account for the small difference between loan rates and deposit rates in Japan. It is hardly surprising that commercial lending is unattractive at a rate comparable to that of long-term bonds. The question is why commercial banks did not raise their loan rates to make such lending more profitable for them. Fukao attributes this to competition that the commercial banks faced from government-sponsored financial institutions on the one hand and governance problems on the other. ${ }^{12}$

\footnotetext{
9 This argument is developed in McKinnon and Ohno (1997).

${ }^{10}$ Krugman (1998) was the first to develop and popularise the analysis that Japan might be in a liquidity trap.

11 On moral hazard grounds, it is possible to argue that the reverse will be the case.

12 Goyal and McKinnon explicitly reject the view that it is competition from government-sponsored financial institutions that is responsible for the low margins of Japan's commercial banks.
} 
In Japan, government-sponsored financial institutions have about 25 per cent of the loan market, 33 per cent of the deposit market and 40 per cent of the life insurance market. Their loan rates are similar to those of private commercial banks, but their loans usually have longer maturities and government-sponsored financial institutions typically accept early repayment without penalty. According to Fukao, the terms of the loans being offered by government-supported financial institutions do not make them profitable. But since these institutions receive about one trillion yen per year in direct and indirect subsidies, this is not a problem for them.

Even if commercial banks did not face competition from government-sponsored financial institutions, Fukao argues that they would have great difficulty operating profitably in Japan's deregulated environment in which the MOF no longer provides banks with regulatory rents. ${ }^{13}$ Commercial banks do not face strong pressures from shareholders to operate efficiently. The commercial banks' largest shareholders are mutual-life-insurance companies. Mutual-life-insurance companies do not have shareholders. Management is supposedly accountable to its policy holders, but with the policy holders' representatives selected by management, Fukao concludes that there is no accountability at all and no incentives in place for insurance companies to use resources efficiently and demand high return on the investments that they do make. ${ }^{14}$ This lack of pressure on the management of the commercial banks' principal stockholders, in turn, insulates the commercial banks' management from governance pressure to stop unprofitable lending activities. Like Goyal and McKinnon, Fukao believes that Japanese banks suffer from more than a bubble-attributable bad loan problem. If bad loans were the only problem facing commercial banks, a capital infusion might be enough to solve the problem. Given competition from government-sponsored financial institutions and the governance problems facing commercial banks, even after a round of capital infusion like that in 1999, allowing older non-performing loans to be written off, the continuing absence of operating profits, not to mention the emergence of new non-performing loans, means that a new round of infusions will soon be required according to Fukao.

\section{d. Community Banking and Structural Change}

Unlike Fukao, Nishimura and Kawamoto do not see the Japanese banking system's long-standing failure to write off non-performing loans as a corporate governance issue. Rather they view Japanese commercial banks as having throughout the last half

\footnotetext{
${ }^{13}$ It was these rents that allowed Japanese commercial banks to compete successfully with governmentsponsored financial institutions from the early 1950s to the late 1980s.

${ }^{14}$ Banks and the mutual-life-insurance companies with which they are allied raise capital from one another, creating the false illusion that their balance sheets are far stronger than is actually the case.
} 
century operated according to a community-banking business model. The traditional financial keiretsu view that emphasises the relationship between Japanese banks and large corporations, according to Nishimura and Kawamoto, cannot explain the reluctance of Japanese banks to write off non-performing loans made to small and medium-size enterprises. ${ }^{15}$ This is an important issue because almost half the loans made by Japanese banks are to such firms.

Reasoning by analogy with Japanese labour-management practices, Nishimura and Kawamoto see Japanese commercial banks as seeking long-term relationships, not only with larger firms, but with all their commercial borrowers. ${ }^{16}$ This leads them to eschew short-term profit maximisation in favour of maximising profits over the lifetime of the firm. For Nishimura and Kawamoto, the communitybanking business model provides a rational explanation for why commercial banks continue to offer loan rates that are unprofitable for them and why commercial banks continue to lend to firms that are in default on their repayments.

Nishimura and Kawamoto recognise that the community-banking business model was a product of a period when the Japanese economy was expanding relatively rapidly and when asset prices were rising. Given that this was a characteristic of Japan for 40 years prior to 1990, it is hardly surprising that practices of community banking became institutionalised and are difficult to change in what is now a very different environment.

\section{RESOLVING JAPAN'S ECONOMIC PROBLEMS}

The problems that Japan faces today are still worse than they were earlier in the Lost Decade. To cite only two examples: (1) the public debt outstanding as a percentage of GDP is orders of magnitude higher than it was in the early 1990s; and (2) commercial bank balance sheets while already weakened in the early 1990s are far weaker today. The Symposium papers make many recommendations as to what needs to be done to bring Japan out of its long-standing recession. From the perspective of a decade ago, what is remarkable is that no one is recommending the use of conventional monetary and fiscal policies to solve Japan's problems. There is a consensus among the papers that using fiscal policy to stimulate the economy is not an option because the government's deficit and outstanding liabilities are already so high. ${ }^{17}$ There is also a consensus that,

\footnotetext{
${ }^{15}$ On financial keiretsu, see Aoki and Saxonhouse (2000).

${ }^{16}$ For an analysis of Japan's permanent employment practices that provides perspective on the community-banking business model, see Boberg (2000).

${ }_{17}$ As noted, Kuttner and Posen (2001) and Ahearne et al. (2002) do not share this view. In January 2003, Prime Minister Koizumi abandoned his long-standing opposition to using fiscal policy to stimulate the economy and abandoned his pledge to cap new government bond issues at 30 trillion yen (Nihon keizai shimbun, 31 January, 2003).
} 
whatever the causes, Japan is facing a liquidity trap, and that conventional monetary policy will not restore Japan's economic health.

\section{a. Exchange Rate Stability}

If conventional fiscal and monetary policies will not work, what policies are recommended? Goyal and McKinnon see Japan mired in a low-interest rate liquidity trap because of a negative risk premium. The negative risk premium arises from: (1) decades of accumulation of dollar assets within Japanese financial institutions; and (2) fluctuations in the yen/dollar exchange rate, which increase the risks to yen-based firms from holding these dollar assets. Because running trade deficits cannot suddenly reverse the cumulative effect of decades of trade surpluses, according to Goyal and McKinnon, the only immediate policy instrument available for reducing the foreign exchange risk in Japanese financial intermediaries is to stabilise the yen/dollar exchange rate in a completely convincing fashion. ${ }^{18}$ With the full cooperation of the United States, such a policy could be successful. With the end of the negative risk premium, nominal interest rates would rise, permitting the BOJ to once again use monetary policy to reinflate the economy, while also restoring the profitability of bank lending.

\section{b. Changing Price Expectations}

Goyal and McKinnon view a rise in the nominal interest rate as a precondition for making effective use of monetary policy. In contrast, Ito and Fukao believe that monetary policy can be effective, even at a nominal interest rate of zero, provided the BOJ sets a credible inflation target of zero to three per cent. ${ }^{19}$

How such credibility might be achieved in the midst of deflationary conditions is rather uncertain. Five different channels that might achieve this end have been suggested. These channels include: (1) monetising the Japanese government debt; (2) the purchase by the MOF and the BOJ of privately-held non-governmental domestic financial and non-financial assets; ${ }^{20}$ (3) the purchase by the BOJ of foreign financial assets; ${ }^{21}(4)$ manipulation of the consumption tax; and (5) introduction of time-limited scrip and currency taxes.

\footnotetext{
${ }^{18}$ How this might be done is laid on in more detail in McKinnon and Ohno (2001).

19 The magnitude of the target will depend on what is assumed about Japan's full employment real interest rate.

${ }^{20}$ In a more limited way than discussed here, the BOJ has already purchased some commercial paper, corporate bonds, and asset-back securities under repurchase agreements. These purchases have all been made from financial institutions. Thus far, none have been made in the open market or directly from corporations. See Nihon keizai shimbun (17 March, 2003).

21 While the MOF has direct jurisdiction over foreign exchange trading, monthly purchases of 200-300 billion yen in foreign bonds are within the BOJ authority. See Nihon keizai shimbun (18 February, 2002).
} 
None of these channels can work without the public perception that a long-term shift in government policy has taken place. If the BOJ intervention in private assets markets in Japan (for equities, corporate bonds, land, golf club memberships, woodblock prints, ceramics, or National Treasures and the like) or in foreign assets markets abroad is seen as temporary, in a deflationary environment, the supply of most such assets at the current price is likely to be highly elastic, making significant increases in Japanese prices, or a significant depreciation of the yen, much more difficult. ${ }^{22}$

\section{(i) Printing money}

Monetising the Japanese government debt (the direct purchase of newly issued public bonds by the BOJ) has been much discussed in recent years in Japan. Under intense political pressure from elements in the Liberal Democratic Party, the BOJ has begun to buy long-term government bonds from the public, as well as from banks, but it has not yet purchased any such bond than has been issued more recently than one year. The BOJ has resisted buying new issues on the grounds that this would lead to the perception of fiscal indiscipline.

Ihori et al. surmise that concern about the size of Japan's public debt weakens the private sector's incentive to spend. ${ }^{23}$ This suggests that the real issue may be less whether or not the BOJ is buying new bond issues, but rather what it does with a bond issue after its purchase. If Ihori et al. are correct, and if it is the size of gross public debt and not only net public debt that is a matter of concern, then if the BOJ undertakes some polite equivalent of burning government bonds, deficit financing can proceed, in principle, without Japan's fiscal position becoming unsustainable. ${ }^{24}$

Historically a government will monetise its debt when investors do not have enough confidence that the government will honour its debts and are reluctant to buy its bonds. This has not been a problem that Japan has faced to date. Quite the contrary. Monetising the debt means that a government is getting its fiscal house in order not by cutting expenditures or increasing taxes, but rather by printing money. In the tradition of prudent central banking, the BOJ fears that an overt move to allow government expenditures to be made without the constraint of having to raise revenues through taxes or bonds will lead to such a dramatic change in price expectations that the bond market may suffer a severe decline. Fukao voices concern about this possibility in his paper. Japanese government bonds form an important part of the balance sheet of almost all Japanese financial

${ }^{22}$ For a discussion of how yen depreciation can promote Japanese economy recovery, see Svensson (2001).

${ }^{23}$ For a contrary view, once again see Kuttner and Posen (2001) and Ahearne et al. (2002).

${ }^{24}$ On the difference between Japan's net and gross public debt, see OECD (2000, p. 65). On monetising a portion of the Japanese debt, see Bernanke (2000, p. 163). 
institutions. A severe decline in the bond market would destroy what equity remains in the banking system. As Fukao notes, the very change in price expectations that he seeks that would allow higher rates on loans permitting banks to once again operate profitably might be self-defeating. From this perspective, the Japanese economy is on a knife-edge. Because of the size of the public debt, the Japanese public, concerned that in the future the government will have either to cut back on entitlements or raise taxes, is reluctant to spend. Yet, if the government opts for a third way and prints money, the public might be altogether too ready to spend and more inflation than is desired might ensue.

The problem that Fukao identifies is similar to that faced by the US banking system after World War II. US banks in 1945 were flush with deposits, a disproportionate amount of which was invested in US government obligations. At the time there was concern that if bond prices fell by 20 per cent, the entire banking system could become insolvent. To guard against this possibility, the Federal Reserve System under the influence of the US Treasury supported the US government bond market, notwithstanding the inflationary consequences. ${ }^{25}$ Only after the famous Accord of 1951 between these two government agencies was the Federal Reserve System once again free to pursue a contra-cyclical monetary policy. ${ }^{26}$ Since March 2001, the BOJ has attempted to set what is tantamount to an inflation target at the lower bound (zero) of the range that Fukao and Ito propose. ${ }^{27}$ The US experience of the late 1940s suggests that, in addition to the BOJ Policy Board's pledge to maintain interest rates at zero until deflation is ended, some pledge about supporting the bond market may be in order.

\section{(ii) Manipulating the consumption tax}

Monetary policy is not the only way to change price expectations. Both Ito and Ihori et al. note the important impact that the increase in Japan's consumption tax from three to five per cent in April 1997 had on Japan's recovery. During the year-and-a-half before Japan increased its consumption tax, the economy expanded faster than that of any other OECD country. During the quarter before the consumption-tax increase, Japan experienced a rate of GDP growth, a rate of growth of consumption expenditures, and a rate of growth of business investment all unmatched throughout the entire post-bubble period. This expansion came at a cost of later growth. Unlike Ito, Ihori et al. hold that, while the timing of this tightening of fiscal policy was unfortunate in view of the financial crisis that occurred in Asia that summer together with the collapse of two major financial institutions later that year, the negative impact of this policy was

\footnotetext{
25 See Samuelson (1948, pp. 354-55).

${ }^{26}$ See Samuelson (1961, p. 397).

27 For a discussion of this, see Saxonhouse (2003).
} 
short-lived and cannot be held responsible for aborting Japan's recovery from the Lost Decade.

Ihori et al.'s perspective has led to proposals that Japan might temporarily lower the consumption tax to stimulate spending combined with a pre-announced increase well above five per cent in the future. ${ }^{28}$ Alternatively, it has been suggested that inflationary expectations might be legislated by having Japan's Diet agree to a staggered set of pre-announced consumption-tax increases over a fiveyear period. ${ }^{29}$ These proposals combine an unusually credible set of inflation targets with measures that attempt to resolve Japan's fiscal crisis. The deflationary impact of higher taxes would be more than offset here in the short-run by increased private spending. To the extent that Ihori et al. are correct and concerns over the sustainability of Japan's fiscal situation is affecting consumer spending, the resolution of this problem may soften the longer-run impact on consumer spending of higher taxes. Even if it does not, with price expectations reversed, monetary policy is once again free to play a role in stabilisation policy.

\section{(iii) Taxing currency}

Changing price expectations is needed as a means of lowering the real interest rate when it is assumed that the nominal interest rate cannot be pushed below zero. There are policies, however, that can push the nominal interest rate below zero, and by doing so remove the burden of creating inflationary expectations in a deflationary environment. Nominal interest rates are conventionally assumed not to be able to go below zero because no lender will accept a return less than zero when the option of holding currency at zero cost is available. But suppose that currency is taxed by the government so that the cost of holding it rises above zero. In this event, it does become possible for the nominal interest rate to fall below zero. ${ }^{30}$ Happily, taxing currency has some of the same advantages as raising the consumption tax in that it promotes increased spending even while it helps to resolve Japan's fiscal problems.

One means of implicitly taxing currency is to have it lose its value in a prearranged periodic fashion following its issue. An extreme version of this might be government-issued scrip that has value only for a fixed period of time. Under pressure from Komeitō, a junior member of the three-party ruling coalition, Japan conducted a limited experiment with such a programme in 1999 by issuing scrip to families with children and to the elderly. This scrip retained its value for six months. The experiment, while extremely interesting, has not been repeated. ${ }^{31}$

\footnotetext{
28 See Suzuki (2000) and Feldstein (2001).

29 See Saxonhouse (1999) and Yasuba (2002). Vogelsgang (1999) recommends a cut in the consumption tax to zero and a staggered increase back to its original level.

${ }^{30}$ How this might be done is discussed in Buiter and Panigistzoglou (1999).

31 For details and an evaluation of this programme, see Shimizutani (2002).
} 


\section{(iv) More reform of the financial system}

In contrast to suggestions made that Japanese economic recovery can be promoted by reforming international financial arrangements and by the adoption of unconventional monetary and fiscal policies, Fukao and Nishimura and Kawamoto offer proposals to alter Japan's economic structure. Fukao wishes to promote competition in the financial services market by removing the public subsidies given to government-sponsored financial institutions. Unlike the usual situation, in this case, Fukao believes that promoting competition will raise rather than lower the price of financial services. This price increase, by allowing firms in the financial services sector that do not receive subsidies to operate profitably, will enhance rather than detract from national welfare.

Even while Fukao, like Prime Minister Koizumi, is effectively recommending privatising government-sponsored financial institutions, Nishimura and Kawamoto are recommending the creation of new ones. While believing that the range of community-banking practices should be circumscribed, Nishimura and Kawamoto mention that a place remains for such activities. They suggest that banks that retain this objective as their primary focus should be transformed into quasi-non-profit community organisations. The remaining firms in the banking sector would be expected to operate in such a way as to maximise shareholder value. In the current environment with so many borrowers whose credit is so poor, this should mean a substantial increase in the interest rates charged on many loans to reflect the risk involved in making them. Like Goyal and McKinnon and Fukao, Nishimura and Kawamoto believe that the key to the renewed health of the banking system is a greater spread between the interest charged on loans and the interest paid on deposits. But unlike Goyal and McKinnon and Fukao, Nishimura and Kawamoto see a structural change in the way that banks operate as the key to achieving this.

\section{(v) Other supply-side changes}

The structural, or supply-side problems, facing the Japanese economy are not confined to banking. To cite just one additional area among many others, just as the critical channel of credit creation and capital allocation cannot be restored to health without a change in the Government's relationship to this sector and a change in the governance of banks, so changes in educational and social security policies and a broader change in corporate governance must occur if Japanese economic recovery is going to be facilitated by a more efficient training and allocation of labour. ${ }^{32}$ Inevitably as Fukao emphasises, the recovery of the Japanese economy will mix different strands of demand-side and supply-side changes. ${ }^{33}$

\footnotetext{
${ }^{32}$ For additional discussion of structural changes ongoing in the Japanese economy, see Saxonhouse (1998).

${ }^{33}$ Hayashi and Prescott (2002) stress the primary role of exogenous supply shocks in explaining Japan's performance in the 1990s.
} 


\section{CONCLUSIONS ON JAPAN'S LOST DECADE}

There was nothing inevitable about the late 1980s bubble in Japan. The policy instruments available to the BOJ and the MOF could have averted it. At the same time, given the unusual circumstances in which the bubble developed, it is hardly surprising that Japan acted as it did. As in the United States in the late 1990s, during Japan's bubble, asset prices skyrocketed even while all conventional indicators that govern central bank policy such as the consumer price index, the wholesale price index, and the producer price index remained stable.

Once the bubble collapsed, however, neither the BOJ nor the MOF was quick to reverse policy to fight off the recession that ensued. The evidence presented at this Symposium suggests looser fiscal policy would have been ineffective. On the other hand, with prices still rising in the early 1990s and with short-term interest rates still above three per cent, Japan had not yet fallen into a liquidity trap. Monetary easing, if pursued aggressively, might have been successful. As it was, the BOJ, in error, kept the growth rate of base money extremely low throughout $1991-93 .{ }^{34}$

Japan, for whatever reason, having missed the opportunity to use monetary policy in the early 1990s, faced the last half of the 1990s, as today, unable to use the conventional tools of stabilisation policy to help it to recover. This does not mean that Japan was then, or is now, helpless. As noted, there is a large menu of unconventional fiscal measures, non-standard BOJ (and MOF) market interventions, corporate governance measures, and structural changes in the financial services sector that can help to rescue Japan. What remains discouraging after all these years is the absence of political will to adopt the kind of bold measures that can bring an end to the Lost Decade that goes on and on and on.

\section{REFERENCES}

Ahearne, A. et al. (2002), 'Preventing Deflation: Lessons from Japan's Experience in the 1990s', Board of Governors of the Federal Reserve System, International Finance Discussion Paper, No. 729 (June).

Ando, A. (2002), 'The Elusive Total Budget Outlay of the Japanese Government: An Inquiry into the Japanese National Accounts', Journal of the Japanese and International Economics, 16, 177-93.

Aoki, M. and G. Saxonhouse (eds.) (2000), Finance, Governance and Competitiveness in Japan (Oxford: Oxford University Press).

Bergsten, C. F. (1988), America in the World Economy: A Strategy for the 1990s (Washington, DC: Institute for International Economics).

Bernanke, B. S. (2000), 'Japanese Monetary Policy: A Case of Self-Induced Paralysis?' in R. Mikitani and A. S. Posen (eds.), Japan's Financial Crisis and Its Parallels to U.S. Experience (Washington, DC: Institute for International Economics).

${ }^{34}$ For details, see Montgomery (2000). 
Boberg, P. (2000), Internal Labor Markets in Japanese Firms (University of Michigan Department of Economics Doctoral Dissertation).

Buiter, W. H. and N. Panigistzoglou (1999), 'Liquidity Traps: How to Avoid Them and How to Escape Them,' National Bureau of Economic Research Working Paper No. 7245 (July).

Feldstein, M. (2001), 'Japan Needs to Stimulate Spending,' Wall Street Journal (16 July).

Frankel, J. A. (1991), 'Japanese Finance in the 1980s: A Survey', in P. Krugman (ed.), Trade with Japan: Has the Door Opened Wider? (Chicago: University of Chicago Press for NBER).

Hale, D. (1989), 'Tokyo to the Rescue', Far Eastern Economic Review (24 August), 60-61.

Hayashi, F. and E. C. Prescott (2002), 'The 1990s in Japan: A Lost Decade', Review of Economic Dynamics, 5, 206-35.

Hubbard, R. G. (2002), 'Impediments to Growth in Japan' (Speech before the Japan Information Access Project Symposium, Washington, DC, 8 April).

Johnson, C. (1989), 'Their Behavior, Our Policy', The National Interest, 17, 17-27.

Johnson, C. (1998), 'Economic Crisis in East Asia: The Clash of Capitalism', Cambridge Journal of Economics, 22, 653-62.

Krugman, P. (1998), 'It's Baack: Japan's Slump and the Return of the Liquidity Trap', Brookings Papers in Economic Activity, 137-87.

Kuttner, K. N. and A. S. Posen (2001), 'The Great Recession: Lessons for Macroeconomic Policy from Japan', Brookings Papers in Economic Activity, 93-185.

McKinnon, R. and K. Ohno (1997), Dollar and Yen: Resolving Economic Conflict between the United States and Japan (Cambridge, MA: MIT Press).

McKinnon, R. and K. Ohno (2001), 'The Foreign Exchange Origins of Japan's Economic Slump and Low Interest Liquidity Trap', The World Economy, 24, 279-317.

Montgomery, H. (2000), 'The Role of Regulatory Capital and Bank Credit in the Economy of Japan' (University of Michigan, Department of Economics Doctoral Dissertation).

Organization for Economic Co-operation and Development (OECD) (2000), Economy Survey: Japan, 1999-2000 (Paris).

Ramaswamy, R. and C. Rendu (2000), 'Japan's Stagnant Nineties: A Vector Auto-Regressive Retrospective,' IMF Staff Papers, 47, 259-78.

Samuelson, P. A. (1948), Economics: An Introductory Analysis (1st ed., New York: McGraw Hill).

Samuelson, P. A. (1961), Economics: An Introductory Analysis (5th ed., New York: McGraw Hill).

Saxonhouse, G. R. (1998), 'Structural Change and Japanese Economic History: Will the 21st Century be Different?' American Economic Review, 88, 408-11.

Saxonhouse, G. R. (1999), ‘Japan's Growth Conundrum', Financial Times (14 June).

Saxonhouse, G. R. (2003), 'Prospective Japanese Economic Recovery: Perspectives from European Economic Recovery in the 1930s', in Stern (2003).

Shimizutani, S. (2002), 'Consumption and Tax Policy in Japan in the 1990s: Evidence from Household Data' (University of Michigan, Department of Economics Doctoral Dissertation).

Sims, C. A. (1980), 'Macroeconomics and Reality', Econometrica, 48, 1- 48.

Stern, R. M. (ed.) (2003), Japan's Economic Recovery: Commercial Policy, Monetary Policy, and Corporate Governance (Cheltenham, UK: Edward Elgar, forthcoming).

Suzuki, Y. (2000), 'Strategies for Overcoming Japan's Economic Crisis', in M. Aoki and G. R. Saxonhouse (eds.), Finance, Governance and Competitiveness in Japan (Oxford: Oxford University Press).

Svensson, L. E. O. (2001), 'The Zero-Bound in an Open Economy: A Fool-Proof Way of Escaping the Liquidity Trap', Monetary and Economic Studies, 19, 277-321.

Vogelsgang, M. (1999), 'How to Rescue Japan: Proposal of a Staggered VAT Reform', University of Potsdam, European Institute for International Economic Relations, Discussion Paper, No. 61 (May).

Werner, R. A. (2002), 'Administrative Guidance and Monetary Policy in Japan', Asian Economic Journal (forthcoming).

Yasuba, Y. (2002) Asahi Shimbun (27 March). 